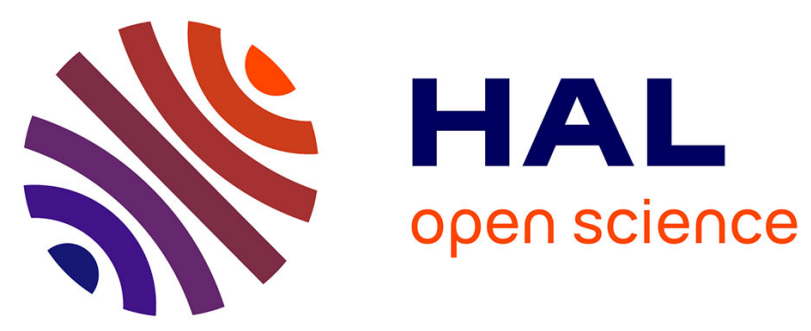

\title{
Carbon dioxide and energy flux partitioning between the understorey and the overstorey of a maritime pine forest during a year with reduced soil water availability
}

Nathalie Jarosz, Yves Brunet, Eric Lamaud, Mark Irvine, J.-M. Bonnefond, Denis Loustau

\section{To cite this version:}

Nathalie Jarosz, Yves Brunet, Eric Lamaud, Mark Irvine, J.-M. Bonnefond, et al.. Carbon dioxide and energy flux partitioning between the understorey and the overstorey of a maritime pine forest during a year with reduced soil water availability. Agricultural and Forest Meteorology, 2008, 148 (10), pp.1508-1523. 10.1016/j.agrformet.2008.05.001 . hal-00351201

\section{HAL Id: hal-00351201 \\ https://hal.science/hal-00351201}

Submitted on 8 Jan 2009

HAL is a multi-disciplinary open access archive for the deposit and dissemination of scientific research documents, whether they are published or not. The documents may come from teaching and research institutions in France or abroad, or from public or private research centers.
L'archive ouverte pluridisciplinaire HAL, est destinée au dépôt et à la diffusion de documents scientifiques de niveau recherche, publiés ou non, émanant des établissements d'enseignement et de recherche français ou étrangers, des laboratoires publics ou privés. 
Carbon dioxide and energy flux partitioning between the understorey and the overstorey of a maritime pine forest during a year with reduced soil water availability

Nathalie Jarosz ${ }^{*}$, Yves Brunet, Eric Lamaud, Mark Irvine, Jean-Marc Bonnefond \&

Denis Loustau

INRA, Ephyse, BP 81, 33883 Villenave d'Ornon Cedex, France

Agricultural and Forest Meteorology

*Corresponding author:

Nathalie Jarosz

New address :

CESBIO, UMR 5126, CNES-CNRS-UPS-IRD

24 rue d'Embaquès

32000 Auch

FRANCE

$\mathrm{Ph}: 33(0) 562617344$

Fax : $33(0) 562617358$

email: nathalie.jarosz@cesbio.cnes.fr 


\begin{abstract}
.
Carbon dioxide, water vapour and energy fluxes were measured above and within a maritime pine forest during an atypical year with long-lasting reduced soil water availibility. Energy balance closure was adequately good at both levels. As compared with what is usually observed at this site the ecosystem dissipated less energy via latent heat flux and more via sensible heat flux. The understorey canopy was responsible for a variable, significant component of the whole canopy fluxes of water vapour and carbon dioxide. The annual contribution of the understorey was 38\% (154 mm) of the overall evaporation (399 mm) and $32 \%$ (89 $\mathrm{mm}$ ) of the overall sensible heat flux $(274 \mathrm{~mm})$. The participation of the understorey reached $45 \%$ of the overall evaporation and $30 \%$ of the daytime overall assimilation during significant soil water deficit periods in summertime. Even during winter, understorey photosynthesis was consistent as it compensated soil and understorey respiration. The ecosystem behaved as a sink of carbon, with a negative annual carbon budget $\left(-57 \mathrm{gC} \mathrm{m}^{-2}\right)$. However, due to high soil water deficit, the annual ecosystem GPP was $40 \%$ less than usually observed at this site. This budget resulted from a sink of $-131 \mathrm{gC} \mathrm{m}^{-2}$ for the overstorey and a source of $+74 \mathrm{gC} \mathrm{m}^{-2}$ for the understorey. Moreover, on an annual basis the overstorey layer contributed to almost two thirds of the ecosystem respiration. Finally, the effect of longlasting soil water deficit on the maritime pine forest was found more important than the effect of the heat wave and drought of summer 2003.
\end{abstract}

Keywords: $\mathrm{CO}_{2}, \mathrm{H}_{2} \mathrm{O}$, eddy covariance, conifer forest, GPP, respiration, WUE 


\section{INTRODUCTION}

Forests extend over large areas and have a major contribution to total energy and mass exchange between the biosphere and the atmosphere. Many studies have been conducted worldwide to evaluate carbon dioxide and water vapour fluxes over various types of forests (Baldocchi et al., 2001; Valentini 2003). However, although forests are greatly variable in structure and composition, they have often been considered as a whole and the respective contributions of the overstorey and the understorey have rarely been quantified. Yet, the fluxes from the bottom layers may constitute a significant part of the overall ecosystem exchanges (Misson et al., 2007).

According to the leaf area index (LAI) of the overstorey, light penetrates more or less deeply in the understorey layer. The LAI of southern pine forests is relatively low and almost constant during the year, owing to the permanent presence of needles. As compared with dense stands, turbulent transport is expected to be more efficient in open stands and the available energy close to the ground surface to be larger (e.g. Baldocchi and Vogel, 1996 ; Misson et al., 2007). Additionally, understorey vegetation is usually taller in open stands, thus enhancing evaporation. This implies that mass and energy exchange is expected to be significant at bottom layers in such open environments as temperate pine forests.

In order to understand and quantify the various sources and sinks within the forest canopy, measurements of mass and energy exchange can be performed at various levels. The eddycovariance (EC) method has been extensively used to estimate energy and mass exchange at the forest scale in programmes such as Euroflux (Aubinet et al., 2000) and FLUXNET (Baldocchi et al., 2001). The feasibility of eddy-flux measurements just above the forest floor has also been considered in various types of forests like temperate broad-leaved, boreal coniferous, coniferous and deciduous forests (e.g. Baldocchi and Vogel, 1996; Baldocchi et al., 2000; Blanken et al., 1997; Lamaud et al., 2001; Launiainen et al., 2005; Wilson et al., 2000). Such measurements have two well-known limitations: (i) flux estimates are usually representative of a much smaller area than those performed above the canopy (Baldocchi, 1997; Wilson and Meyers, 2001); (ii) the underlying assumptions of the EC method are not expected to be generally valid in the conditions of highly non-stationary and turbulent flow regime prevailing there (Blanken et al., 1998; Baldocchi et al., 2000). However they have proved to be very useful to determine flux partitioning between the overstorey and the understorey (Misson et al., 2007). But, to our knowledge, none of such measurements 
performed just above the forest floor has been used so far to quantify the effect of long lasting reduced soil water availability on mass and energy flux partitioning.

An increasing number of studies deal with either drought or heat effect on ecosystem functioning. They show a reduction of water fluxes, net primary productivity and total ecosystem respiration (e.g. Ciais et al., 2005, Granier et al., 2007), usually over short periods of time occurring in summer. However, little is known about possible consequences of longer lasting periods of heat or drought occurring not only in summer but also in winter, whereas such events are expected to be more frequent in the near future (Meehl \& Tebaldi, 2004; Giorgi, 2006).

In the present study water vapour $\left(\mathrm{H}_{2} \mathrm{O}\right)$ and carbon dioxide $\left(\mathrm{CO}_{2}\right)$ fluxes were measured with the EC method both above and below a maritime pine forest canopy over a full year characterized by a long lasting period of reduced soil availability. The aim is twofold: (i) to partition above-canopy energy and $\mathrm{CO}_{2}$ fluxes between the overstorey and understorey components and (ii) to analyse the effect of soil water availability on the fluxes at both levels.

\section{MATERIAL AND METHODS}

\subsection{Site characteristics}

The experimental site of Le Bray is located in the Landes forest about $20 \mathrm{~km}$ South-West of Bordeaux (latitude 4443’1.6” N, longitude 046’9.5”W, altitude $62 \mathrm{~m}$ ) in France. The plot is flat and composed of maritime pine (Pinus pinaster Ait.) planted in 1970 and covering about 16 ha. Mean annual rainfall over the 1970-1999 period is $972 \mathrm{~mm}$. The trees are distributed in parallel rows along a northeast-southwest axis, with an inter-row spacing of $4 \mathrm{~m}$. In 2002 the canopy crown extended between 12 and $20 \mathrm{~m}$ above soil surface and stand density was about 410 trees $\mathrm{ha}^{-1}$. The leaf area index (LAI) of the overstorey evaluated by various optical methods (Demon, LAI 2000) was $2.4 \mathrm{~m}^{2} \mathrm{~m}^{-2}$ on average.

The understorey mostly consists of grass, mainly purple moor-grass Molinia coerulea L. Moench, that accounts for more than $90 \%$ of the LAI when it is well developed (Loustau and Cochard, 1991). In 2002 the understorey LAI, estimated by a destructive method, varied from 0 in winter to $1.6-1.9 \mathrm{~m}^{2} \mathrm{~m}^{-2}$ in summer when the purple moor-grass was about $0.7 \mathrm{~m}$ high. The soil is a sandy and hydromorphic podzol, with dark organic matter in the first $0.6 \mathrm{~m}$. It is covered by a litter formed by dead needles, dead grass, dead branches and decayed organic matter. A layer of compact sand, barely penetrable by the roots, is located at a depth of about 
$0.8 \mathrm{~m}$. Inorganic sand lies below this layer. The water table level reaches the soil surface during most winters, and drops to a depth between 1.2 and $2 \mathrm{~m}$ in summer.

A $40 \mathrm{~m}$ high instrumented tower is set up in the middle of the stand. The latter is surrounded by similar stands, except in the northwest direction where a clearcut was made at about $200 \mathrm{~m}$ from the tower following the December 1999 storm. This sector was excluded from the present analysis.

\subsection{Eddy covariance and meteorological measurements}

In 2002 turbulent fluxes were measured by two EC systems at 7 and $41 \mathrm{~m}$ above ground. The basic instruments and methods have been standardised throughout the Euroflux network (Aubinet et al., 2000). The present EC system is made of a 3D sonic anemometer Solent, R2, above the canopy and and R3 below (Gill Instruments, Lymington, Hampshire, UK), coupled with an open path $\mathrm{CO}_{2} / \mathrm{H}_{2} \mathrm{O}$ InfraRed Gas Analyzers (IRGA) LI-7500 (LICOR, Lincoln, NE, USA). Instantaneous measurements of the three components of wind velocity, temperature ( $\mathrm{T}$ ) and the molar fractions of $\mathrm{H}_{2} \mathrm{O}$ and $\mathrm{CO}_{2}$ were collected and stored at $20.8 \mathrm{~Hz}$. Turbulent scalar eddy fluxes were then calculated every half hour as the covariance between the vertical wind speed and the scalar variable $\left(\mathrm{CO}_{2}, \mathrm{H}_{2} \mathrm{O}, \mathrm{T}\right)$. The EC system located above the canopy gives fluxes representative of the whole ecosystem, whereas the system located below the canopy gives fluxes from the understorey, that includes the soil and the vegetation covering the soil. In what follows, 'overstorey' refers to the difference between the two levels of EC measurements, and therefore corresponds to the pine trees alone.

Net radiation $\left(R_{n}\right)$ was directly measured with a Radiation and Energy Balance Systems model Q7 (REBS, Seattle, USA). Global radiation $\left(\mathrm{R}_{\mathrm{g}}\right)$ was measured with a CE180 pyranometer (Cimel Electronique, Paris, France). Incident and diffuse photosynthetically active radiation (PAR) was measured above the canopy using a sunshine sensor BF2 (Delta-T Devices, Cambridge, UK). Mean wind speed and direction were measured with a wind vane anemometer (5103 Young, Traverse City, Michigan, USA), and air temperature and relative humidity with a HMP45 (Vaisala, Helsinki, Finland). All these measurements were performed at $41 \mathrm{~m}$ above ground. Rainfall was measured at a height of $24 \mathrm{~m}$ on a nearby tower, just above the top of the trees, with a rain gauge ARG100 (Campbell Scientific, Logan, USA). Atmospheric pressure was measured at $2 \mathrm{~m}$ above ground using a PTB101B Barometric Pressure Transmitter (Vaisala, Helsinki, Finland). Soil heat flux (G) was measured using two flux plates (Campbell Scientific, Shepshed, UK) and corrected by an estimation taken from a 
two-step version of the null-alignment method using soil temperature, water content and bulk density measurements between the soil surface and $1 \mathrm{~m}$ depth (Ogée et al., 2001). Four temperature profiles were set up at depths 1, 2, 4, 8, 16, 32, 64 and $100 \mathrm{~cm}$ using 32 homemade thermocouples. Soil water content (SWC) was measured at 0.05, 0.23, 0.34 and $0.8 \mathrm{~m}$ depth using a Time-Domain Reflectometry (TDR) Trase (Soil Moisture Equipment Corp., Santa Barbara, CA) sensor at three different locations. Soil bulk density was measured gravimetrically from samples collected at various depths and three locations in the vicinity of the other soil measurements. All signals were sampled every $10 \mathrm{~s}$ on CR10X, CR21X and CR23X Campbell data loggers (Campbell Scientific, Logan Utah, USA) and averaged every half hour.

\subsection{Methods}

\subsubsection{Eddy covariance fluxes}

The fluxes were computed and corrected for 30 min periods using the EdiRe software (University of Edinburgh, UK) as recommended by Aubinet et al. (2000): after occasional spikes were removed from the raw time series, coordinate axes were rotated so that mean vertical velocity was zero and mean horizontal velocity was aligned with the mean wind direction; water vapour fluxes were corrected for the effect of density fluctuations (Webb et al., 1980). Half-hourly flux values that were missing or did not meet the quality criteria were gap-filled. Above the canopy, the proportion of the missing data was $17 \%$ of $\mathrm{CO}_{2}, 27 \%$ of latent heat and $14 \%$ of sensible heat fluxes. As expected, the unsteady nature of turbulence below the canopy caused a greater proportion (40\%) of fluxes measured above the forest floor to be rejected. The detailed method applied to fill the gaps in above fluxes can be found in Berbigier et al. (2001). Briefly, gaps were filled on monthly periods using multiple polynomial regressions on the relevant micrometeorological data fitted against the adjacent data, taking care that the weather was similar. As for $\mathrm{CO}_{2}$ fluxes, gap filling was made with reference to direct and diffuse PAR, air temperature and friction velocity $\mathrm{u} *$. Daytime and nighttime data were addressed separately. The method of Falge et al. (2001a,b), based on look-up tables, was chosen to fill the gaps in below-canopy fluxes because it appeared more adapted than the polynomial regressions: if all meteorological data were available, the missing value was replaced by the average value under similar meteorological conditions within a time-window of 7 days, and if no similar meteorological conditions were present, the averaging window was increased to 14 days. 


\subsubsection{Net radiation below the canopy}

The net radiation transmitted below the canopy $R_{\mathrm{nb}}$ was estimated using a radiation transmission model validated at the same site (Berbigier and Bonnefond, 1995), corrected so that the difference between canopy temperature and litter temperature was taken into account (Ogée et al., 2001):

$$
R_{\mathrm{nb}}=R_{\mathrm{nb}}{ }^{\prime}+\left(1-f^{2}\right) \sigma\left\{T_{\mathrm{a} 8 \mathrm{~m}}^{4}-T_{\mathrm{a}_{1}}^{4}\right\}
$$

where $R_{\mathrm{nb}}$ ' is the net radiation below the canopy, calculated using the model of Berbigier and Bonnefond (1995), $\sigma=5.674 \times 10^{-8} \mathrm{~W} \mathrm{~m}^{-2} \mathrm{~K}^{-4}$ is the Stefan constant, $T_{\mathrm{a} 8 \mathrm{~m}}$ is the air temperature at $8 \mathrm{~m}$ above ground, taken instead of the canopy temperature which was not measured, $T_{\mathrm{al}}$ is the litter temperature at the air-litter interface and $f$ is a luminance constant calculated from the LAI:

$$
f=\exp \left(-0.548 \mathrm{LAI}+0.0177 \mathrm{LAI}^{2}\right)
$$

\subsubsection{Gross primary productivity and respiration}

We splitted the $\mathrm{CO}_{2}$ fluxes as measured by the EC method into gross primary productivity, GPP, and respiration, R, using the Reichstein et al. (2005) algorithm that we applied separately on the canopy nighttime fluxes measured at the upper and lower levels. Nighttime data $\left(\mathrm{R}_{\mathrm{g}}<20 \mathrm{~W} \mathrm{~m}^{-2}\right)$ were selected and splitted among consecutive 15-day periods with a 10day overlap, giving a total of 78 data sets. The model is as follows:

$$
\mathrm{R}=\mathrm{R}_{\text {ref }} \times \exp \left(\mathrm{E}_{0}\left(1 / \mathrm{T}_{\text {ref }}-\mathrm{T}_{0}\right)-1 /\left(\mathrm{T}_{\mathrm{a}}-\mathrm{T}_{0}\right)\right.
$$

where $\mathrm{T}_{0}$ is a constant temperature at $-46.02^{\circ} \mathrm{C}, \mathrm{T}_{\mathrm{a}}$ is the air temperature measured above the canopy, and $\mathrm{T}_{\text {ref }}$ is a reference temperature taken at $10^{\circ} \mathrm{C}$. The model parameters, $\mathrm{R}_{\mathrm{ref}}$, the temperature-independent respiration rate, and $E_{0}$, the temperature-dependent activation energy, were calculated for each period. The values obtained were smoothed by sliding averages ( $n=3)$ and used to estimate half-hourly values of ecosystem respiration for the whole year on the entire data set. No filtering criteria were applied on $\mathrm{R}_{\mathrm{ref}}$ and $\mathrm{E}_{0}$ values. Gross primary production was obtained by subtracting the respiration values from the net carbon flux.

\subsubsection{Seasonal and weather classes}

In order to analyse the full-year data set, the data was separated into 6 classes based on the combination of season, air moisture condition and soil water status (Table 1). 'Summer' refers to the period from early May to late October and 'winter' refers to the rest of the year. The distinction between 'well-watered' and 'water-stressed' summer is based on soil water content: under the threshold value of $65 \mathrm{~mm}$ the site experienced a drought and is considered as 'water- 
stressed'; otherwise the conditions are referred to as 'well-watered' (Ogée et al., 2003). We also set a threshold value of $5 \mathrm{hPa}$ on mean daily vapour pressure deficit (VPD) in order to separate wet air conditions from dry air conditions. The number of days per class is larger than 30 in five out of six classes (Table 1).

Table 1. Definition of the six classes used in this study: the soil water status is defined as 'well-watered' when soil water content is larger than $65 \mathrm{~mm}$ and 'water-stressed' otherwise; the air moisture condition is considered as 'wet' when the vapour pressure deficit is less than 5 hPa and 'dry' otherwise; 'summer' refers to the period between May and October and 'winter' to the rest of the year. The number of days $n$ of each class is also indicated.

\begin{tabular}{lllll}
\hline Classes & Season & Soil water status & Air moisture condition & $\mathrm{n}$ \\
\hline 1 & winter & - & wet & 129 \\
2 & winter & - & dry & 41 \\
3 & summer & well-watered & wet & 32 \\
4 & summer & well-watered & dry & 85 \\
5 & summer & water-stressed & wet & 17 \\
6 & summer & water-stressed & dry & 61 \\
\hline
\end{tabular}

\subsubsection{Water use efficiency}

Water use efficiency (WUE) represents the ability of the canopy to assimilate carbon while limiting water loss and as such is defined as the ratio between photosynthesis and canopy transpiration. It is computed here as the regression slope between the GPP and water vapour (E) fluxes, at three levels: the entire ecosystem, the understorey and the pine trees. For the latter, GPP and E are estimated from the differences between measurement above and below the canopy.

\section{RESULTS AND DISCUSSION}

\subsection{Meteorological conditions}

In 2002, the total annual rainfall was $948 \mathrm{~mm}$, which is close to the mean annual value at this site (Fig. 1). However, it can be seen that rainfall mostly occurred during the last three months of the year (374 mm). Maximum global radiation occurred from the beginning of May to the end of August, coinciding with maximum VPD. Annual net radiation below the canopy was $16 \%$ of that above (2613 $\mathrm{MJ} \mathrm{m}^{-2}$ above and $421 \mathrm{MJ} \mathrm{m}^{-2}$ below; table 2). As the overstorey LAI changed by less than $10 \%$ during the year, this proportion varied mostly with the solar elevation angle. From the beginning of May to the end of August, net radiation below the canopy was about $30 \%$ of that above. Air temperature at the bottom layer tended to be slightly 
higher than above the canopy. Mean annual temperature was $13.8^{\circ} \mathrm{C}$ with a half hourly maximum at $34.1^{\circ} \mathrm{C}$ in June and a minimum at small negative values on the first days of January. Daily average wind speed above the canopy varied between 1.21 and $6.37 \mathrm{~m} \mathrm{~s}^{-1}$ whereas at $7 \mathrm{~m}$ above ground it was between 0.20 and $1.52 \mathrm{~m} \mathrm{~s}^{-1}$.

As for soil water availability, year 2002 was atypical. Indeed, soil water content varied from $46 \mathrm{~mm}$ in summer to $169 \mathrm{~mm}$ in winter, which was particularly low compared to other years. The maximum value generally observed in winter can be twice as large as that observed in 2002. Indeed, the cumulative rainfall during autumn 2001 and the following winter was exceptionally low (289 mm, i.e. 259 mm below the 1950-2000 average). The threshold under which the site is considered as 'stressed' correspond to a soil moisture deficit of 25\% (Granier and Loustau, 1994). Knowing that wilting point is $45 \mathrm{~mm}$ and water holding capacity $85 \mathrm{~mm}$, the threshold value is then $65 \mathrm{~mm}$. However, it is important to note that the soil water content did not fall below this threshold during the considered winter whereas it is the case in summer. The water table level did not reach the soil surface as it usually occurs during most winters. It seems the fact that it remains below the root zone depth was enough to stress the ecosystem.

\subsection{Energy balance closure}

Fig. 2 shows the relationship between net radiation and the sum of sensible heat flux, $\mathrm{H}$, latent heat flux, LE, and ground heat flux, G, in 2002. Canopy heat storage was not taken into account since it is negligible at the daily time scale. At this scale the energy balance closure above the canopy shows a slope slightly higher than 1 (Fig. 2a), as already observed by Berbigier et al. (2001) at this site. It can be seen that the closure is excellent on clear days when net radiation is large and less on days when net radiation is close to zero. The latter problem may be attributed to a systematic underestimation of the turbulent fluxes in rainy conditions or alternately to problems with net radiation measurements. Indeed, Kohsiek et al. (2007) showed that using REBS radiometers leads to an underestimation of net radiation by about $5 \%$ in the daytime and an overestimation by about $20 \%$ at night. If we apply these corrections to net radiation, the energy balance closure improves substantially. 

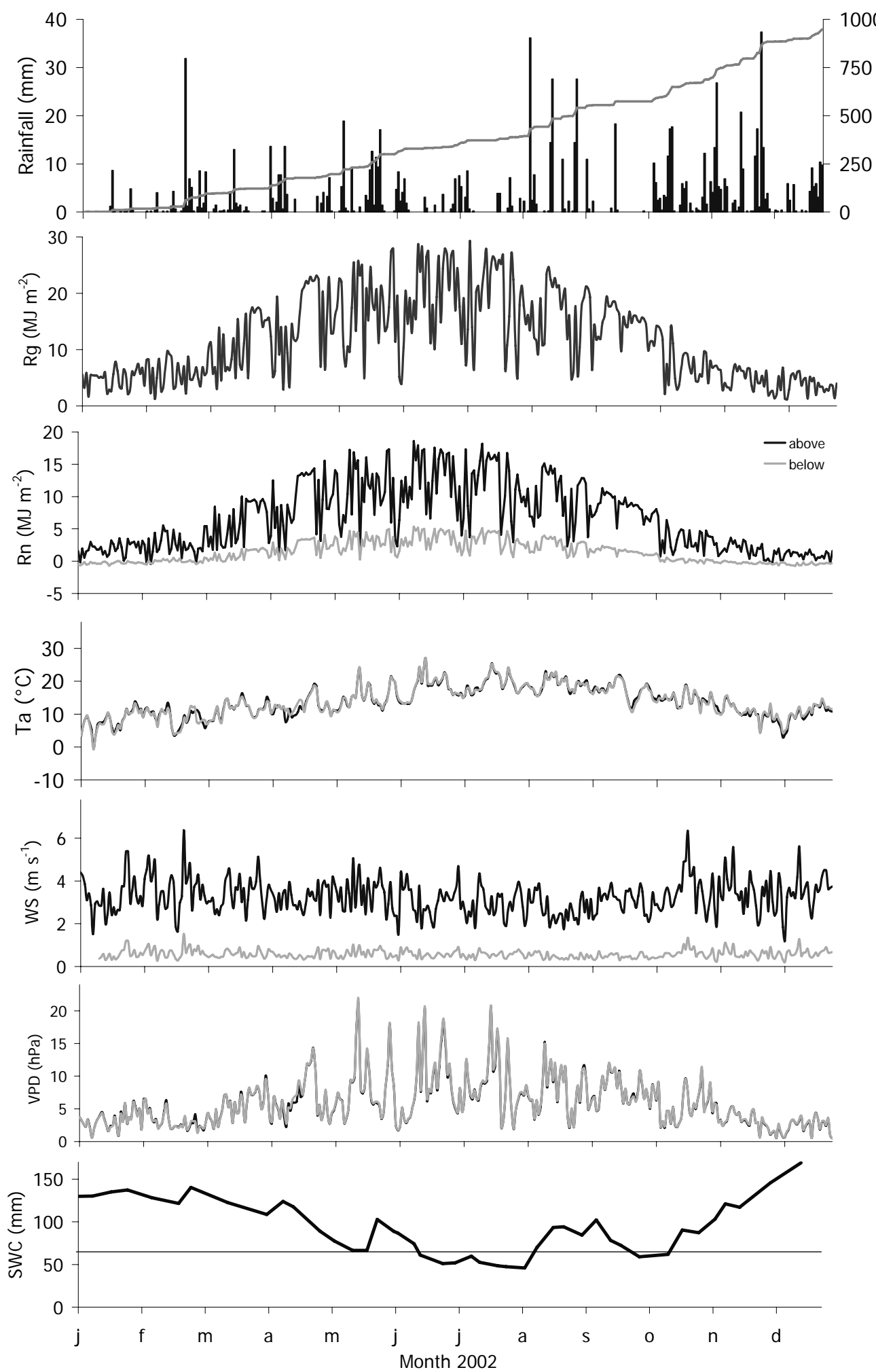

Figure 1. Daily values of rainfall, global radiation (Rg), net radiation (Rn) and soil water content SWC as well as daily means of air temperature (Ta), wind speed (WS), vapour pressure deficit (VPD) in year 2002 at Le Bray site. Rn, Ta, WS and VPD are shown at both levels. Accumulated rainfall is also shown. The horizontal black line marks $65 \mathrm{~mm}$, the threshold value used to delineate well watered from waterstressed periods in summer. 
Table 2. Sum of net radiation Rn, sensible and latent heat fluxes, $H$ and LE, respectively, as measured by eddy covariance above (a.) and below (b.) the forest canopy for the six classes defined in table 1. Overstorey fluxes estimated by the difference between the two systems (o.), along with the ratios of understorey flux to total flux (\%) are also indicated. Annual fluxes are given at the bottom line. Fluxes are in MJ m-2. Total transpiration E (mm) above (a.), below (b.) the canopy and of the overstorey (o.) are shown for the six classes as well as evaporative fraction of understorey and overstorey latent heat flux to radiation (LE/Rn).

\begin{tabular}{|c|c|c|c|c|c|c|c|c|c|c|c|c|c|c|c|c|}
\hline \multirow[t]{2}{*}{ Class } & \multicolumn{3}{|l|}{$\mathbf{R}_{\mathbf{n}}$} & \multicolumn{4}{|l|}{$\mathbf{H}$} & \multicolumn{4}{|l|}{ LE } & \multicolumn{3}{|l|}{$\mathbf{E}$} & \multicolumn{2}{|c|}{$\mathbf{L E} / \mathbf{R}_{\mathrm{n}}$} \\
\hline & a. & b. & $\%$ & a. & b. & o. & $\%$ & a. & b. & o. & $\%$ & a. & b. & o. & a. & b. \\
\hline 1 & 289 & -18 & 6 & -164 & 13 & -177 & 7 & 151 & 52 & 99 & 35 & 60 & 21 & 39 & 0.52 & -2.89 \\
\hline 2 & 345 & 51 & 15 & 103 & 37 & 65 & 36 & 143 & 35 & 108 & 25 & 57 & 14 & 43 & 0.41 & 0.69 \\
\hline 3 & 215 & 39 & 18 & 18 & 11 & 6 & 63 & 91 & 37 & 54 & 41 & 37 & 15 & 22 & 0.42 & 0.95 \\
\hline 4 & 927 & 177 & 19 & 342 & 73 & 268 & 21 & 341 & 145 & 196 & 42 & 137 & 58 & 79 & 0.37 & 0.82 \\
\hline 5 & 83 & 12 & 15 & 1 & 4 & -3 & 73 & 42 & 12 & 30 & 29 & 17 & 5 & 12 & 0.51 & 1.00 \\
\hline 6 & 754 & 160 & 21 & 385 & 84 & 301 & 22 & 228 & 102 & 126 & 45 & 91 & 41 & 50 & 0.30 & 0.64 \\
\hline Total & 2613 & 421 & 16 & 685 & 222 & 460 & 32 & 997 & 384 & 614 & 38 & 399 & 154 & 245 & 0.38 & 0.91 \\
\hline
\end{tabular}



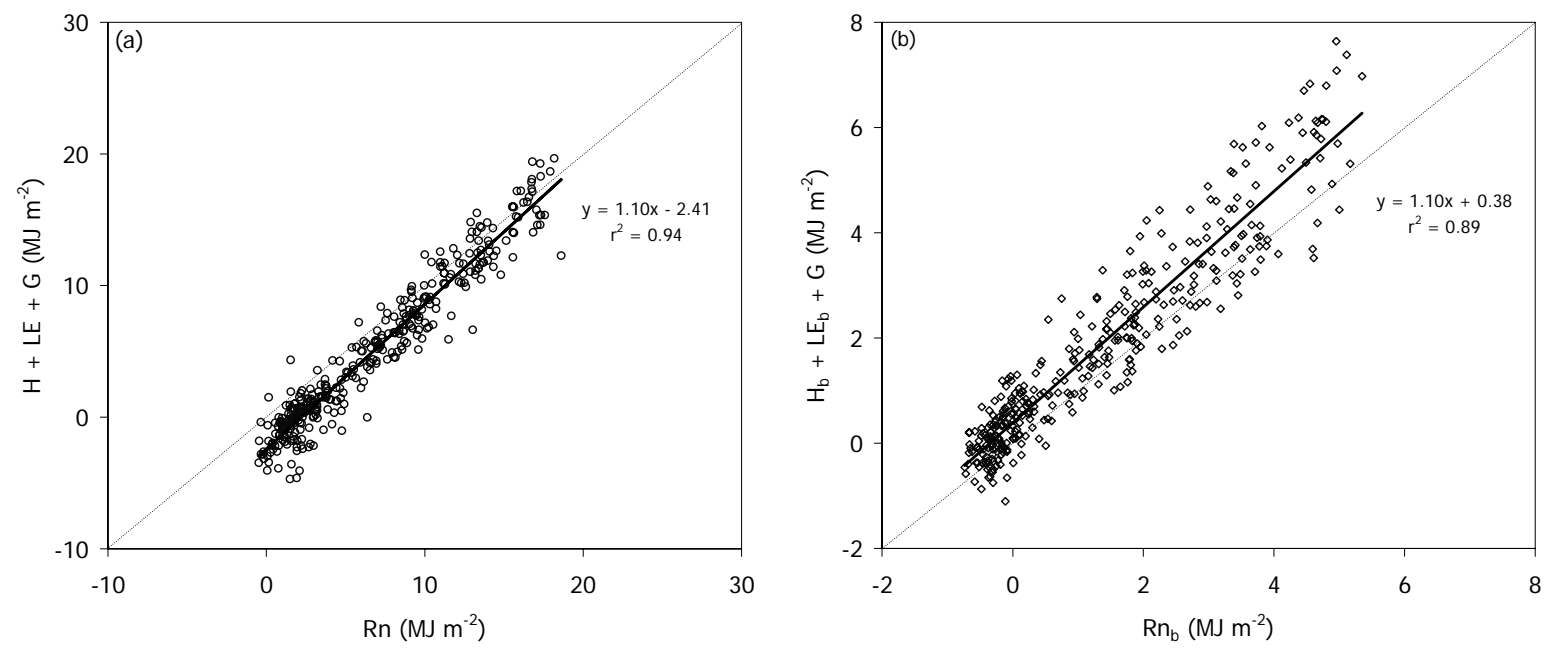

Figure 2. Energy balance closure (a) above the canopy as the relationship between daily values of the sum of sensible and latent heat fluxes, $H$ and LE, respectively and soil heat flux (G) on the one hand and daily values of net radiation $\left(R_{n}\right)$ on the other hand ; (b) below the canopy as the relationship between daily values of the sum of sensible and latent heat fluxes below the canopy, $H_{b}$ and $L E_{b}$, respectively and soil heat flux (G) on the one hand and daily values of net radiation below the canopy $\left(R_{n b}\right)$ on the other hand. $R n_{b}$ is estimated using eq. 2 and 3.

The validity of the EC measurements near the forest floor has already been demonstrated in an earlier study at this site (Lamaud et al., 2001). During the present experiment the energy balance closure is also satisfactorily good at the bottom layer of the forest (Fig. 2b): the slope is the same as above (1.10) and the intercept is $0.38 \mathrm{MJ} \mathrm{m}^{-2}\left(\mathrm{r}^{2}=0.89\right)$. A slope higher than one indicates that either the turbulent fluxes are overestimated or the available energy is underestimated. Daily and annual sums of energy fluxes from EC measurements are subject to errors when missing or rejected data are gap-filled but such cases occur primarily at night when latent and sensible heat fluxes are expected to be small. The most likely reason is therefore the underestimation of net radiation. The model used to estimate net radiation transmitted below the canopy (Berbigier and Bonnefond, 1995) requires an accurate estimation of LAI (Eq. 3), which is difficult to determine in coniferous forests. Optical methods give the best idea of covering foliage but little is known about the possible errors in the resulting estimation (Guyon et al., 2003). Therefore, in order to investigate the influence of errors in LAI estimation on the energy balance closure, we calculated net radiation with LAI values lower by $5 \%$ to $50 \%$ than a reference value (set to $2.4 \mathrm{~m}^{2} \mathrm{~m}^{-2}$ ). The regression slope of the energy balance then becomes lower than that found with the reference value by $4 \%$ to $39 \%$. As the uncertainty in our LAI measurement is between $10 \%$ (i.e. LAI $=$ $2.2 \mathrm{~m}^{2} \mathrm{~m}^{-2}$ ) and $20 \%$ (i.e. LAI $=1.9 \mathrm{~m}^{2} \mathrm{~m}^{-2}$ ), the uncertainty in the energy balance closure below the canopy is between 9 and $17 \%$. This may well account for the discrepancy observed in Fig. 2b. 


\subsection{An overview of fluxes}

Throughout the year, the half-hourly values of sensible and latent heat fluxes as well as the $\mathrm{CO}_{2}$ fluxes show a clear seasonal variation above and below the pine canopy (Fig. 3). They are low in winter and larger the rest of the year at both levels. This seasonal variation corresponds to that of net radiation and the subsequent increase in surface temperature.

The sensible heat flux above the canopy is much larger than the latent heat flux (Fig. 3a, 3b). However, under the canopy the sensible heat flux appears slightly smaller than the latent heat flux. This leads to a lower contribution of the understorey to the overall sensible heat flux (about 10\%) than to the overall latent heat flux (about 50\%). At the bottom level, $\mathrm{H}$ and LE increase as available energy increases and understorey vegetation is growing. It is noticeable that sensible heat flux at the bottom level is rarely negative.

It should be stressed that, due to the low water availability in winter, the pattern of the fluxes was atypical. As expected with a dry soil, maximum values of sensible heat flux tend to be from 22 to 38\% higher than what is usually observed at this site (Berbigier et al., 2001). Conversely, maximum values of latent heat flux tend to be lower by 33 to $36 \%$. Since no understorey flux measurements were performed before 2002, it is not possible to quantify these changes in $\mathrm{H}$ and $\mathrm{LE}$ at the bottom layer and consequently to analyse in depth the respective roles of the understorey and overstorey in the overall fluxes observed in conditions of low water availability.

The annual pattern of carbon dioxide flux $\mathrm{F}_{\mathrm{c}}$ above and below the maritime pine forest results from the balance between photosynthesis and respiration processes (Fig. 3c). Negative values stand for canopies acting as a sink of $\mathrm{CO}_{2}$ and positive values for canopies acting as a source of $\mathrm{CO}_{2}$. It can be seen than $\mathrm{CO}_{2}$ uptake increases between mid-April and mid-July at both levels. Again, maximum fluxes observed above the canopy are between 40 to 50\% lower than in other years (Berbigier et al., 2001).

\subsection{Seasonal variation in energy fluxes}

In 2002, wet and dry air conditions prevailed in 'winter' and in 'summer', respectively (Table 1). Sensible heat flux is between 60 and 80\% higher in dry air conditions (Fig 4.2, 4.4 and 4.6) than in wet air conditions (Fig. 4.1, 4.3 and 4.5). In wet air conditions there is virtually no sensible heat flux originating from the understorey and $\mathrm{H}$ from the trees does not exceed $50 \mathrm{~W} \mathrm{~m}^{-2}$ (Fig. 4.1, 4.3 and 4.5). Peaks occur around midday at both levels. During nighttime in all conditions, $\mathrm{H}$ above the canopy is directed downwards $\left(\mathrm{H}=-30 \mathrm{~W} \mathrm{~m}^{-2}\right.$ on 
average) while under the canopy it remains near zero. This is commonly observed above and within forests (Baldocchi et al., 2000; Wilson et al., 2000; Launiainen et al., 2005). The ratios between the standard deviation and the maximum values of $\mathrm{H}$ show that the uncertainty is very large in wet air conditions (i.e. between 109 and 217\%) when the values of $\mathrm{H}$ are low. In dry air conditions with higher $\mathrm{H}$, the uncertainty is lower.
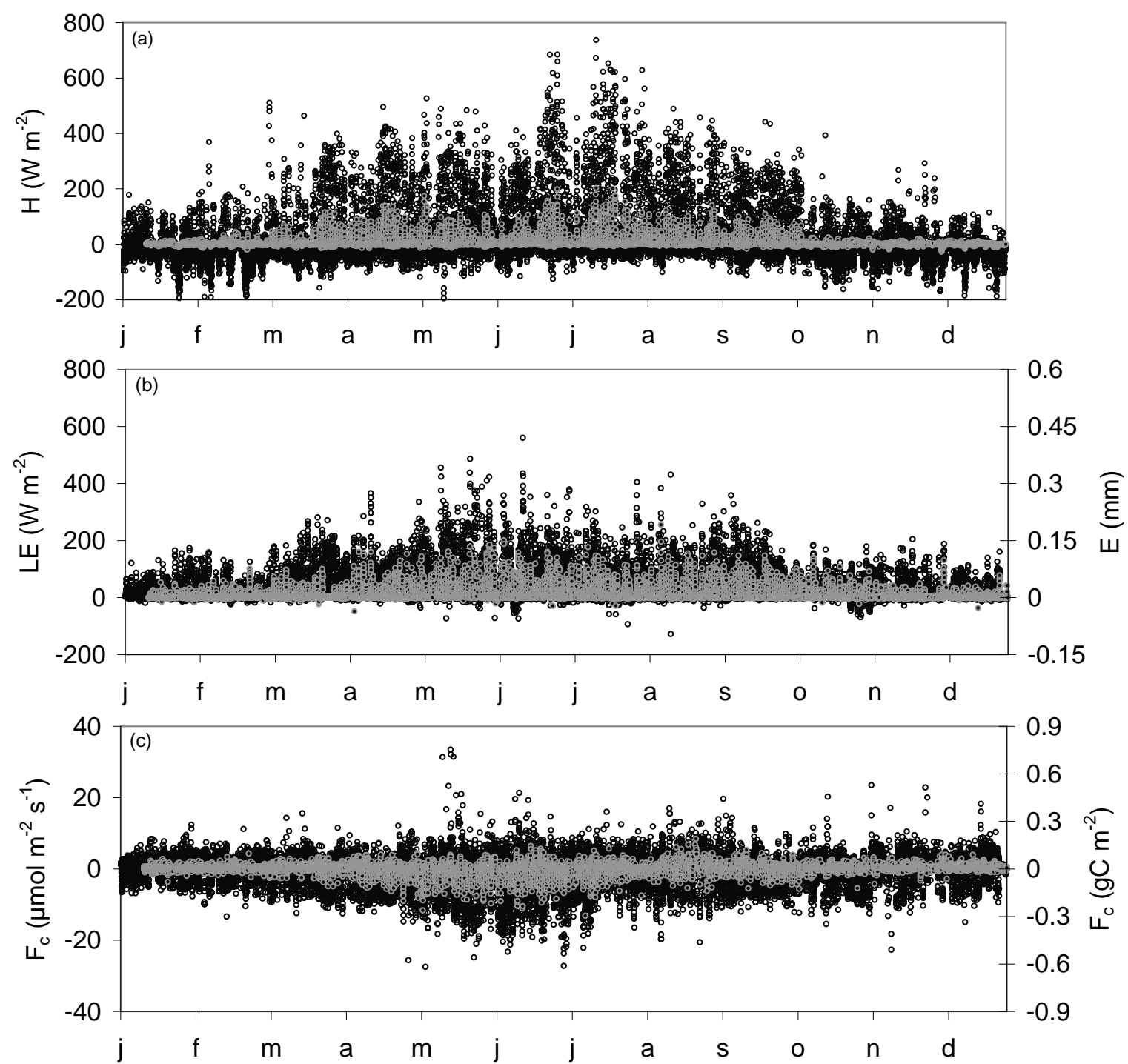

Figure 3. Half-hourly values of (a) sensible heat flux, (b) latent heat flux and (c) carbon dioxide flux, $H$, $L E$ and $F_{c}$, respectively, above the overstorey (open grey symbols) and above the understorey (filled black symbols). Evaporation in $\mathrm{mm}$ and $\mathrm{F}_{\mathrm{c}}$ in $\mathrm{gC} \mathrm{m}^{-2}$ are also indicated.

As sensible heat flux, maximum LE generally occurs around midday at both levels, except in water-stressed and wet air conditions where evaporation from the whole forest appears to be low and delayed towards the mid-afternoon (Fig 5.5). This feature is possibly linked with net radiation which was reduced due to passing clouds or overcast conditions that occur more frequently during wet periods. The evaporation from the whole forest as well as from the soil, whether it is covered or not by a photosynthetically active understorey, is generally higher in 

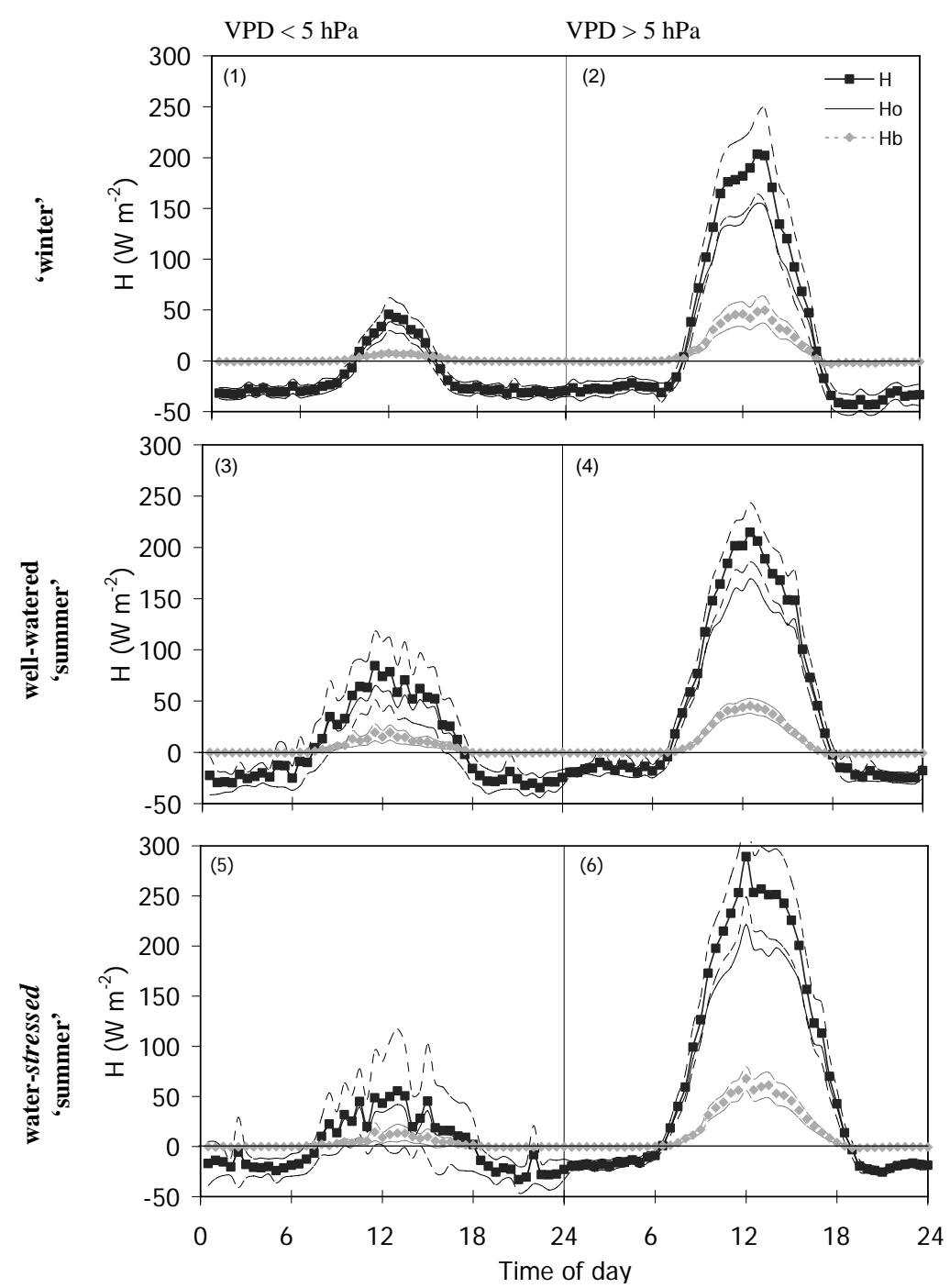

Figure 4. Mean daily course of sensible heat flux above, $H$, and below, $H_{b}$, the canopy averaged over the six classes defined in Table $1 . \mathrm{H}_{\mathbf{0}}$ is the sensible heat flux of the overstorey, deduced from the difference between the two levels. The classes are numbered from top left (1) to bottom right (6). 'Winter' refers to the period between early May to late October and 'summer' to the rest of the year. VPD $<5 \mathrm{hPa}$ stands for wet air conditions and VPD $>5 \mathrm{hPa}$ for dry air conditions. 95\% confidence intervals (lower and upper) for $\mathbf{H}$ (black dotted line) and $\mathbf{H}_{\mathbf{b}}$ (grey dotted line) are also indicated.

dry (Fig. 5.2, 5.4 and 5.6) than in wet air conditions (Fig. 5.1, 5.3 and 5.5). In water-stressed conditions (Fig. 5.5 and 5.6), the evaporation below the canopy does not vary much, particularly in dry air conditions (Fig. 5.6) although the evaporation measured above the canopy decreases following stomatal closure of the needles. The purple moor-grass composing the understorey does not regulate water loss under significant soil water deficit and dry air conditions (Loustau and Cochard, 1991). At our site evaporation from the understorey represents more than $70 \%$ of net radiation in dry air conditions (Table 2), as was already observed over a transpiring vegetative understorey (Blanken et al., 1997). In 'summer' and wet air conditions, these rates can even be closer to $100 \%$ whatever the soil water status is, as observed under a Jack pine stand by Baldocchi et al. (2000). The ratio of 
the standard deviation to the maximum flux value varies from 50 to 104\% above the canopy and from 62 to $110 \%$ at the bottom level, with greater accuracy in dry air conditions.
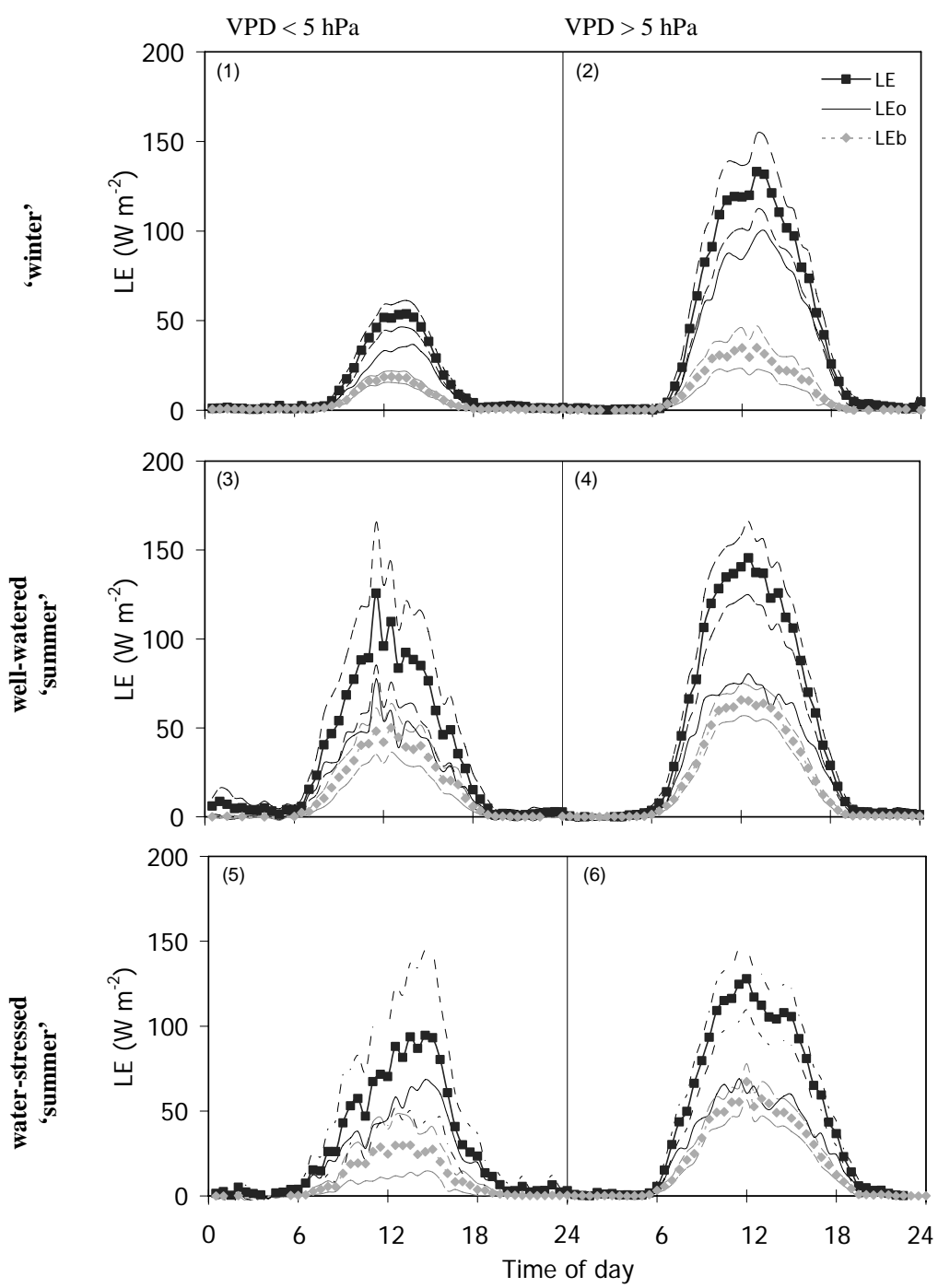

Figure 5. Mean daily course of latent heat fluxes above, $L E$, and below $L E_{b}$, the canopy averaged over the six classes defined in Table $1 . L$ is the latent heat flux of the overstorey, deduced from the difference between the two levels. The classes are numbered from top left (1) to bottom right (6). 'Winter' refers to the period between early May to late October and 'summer' to the rest of the year. VPD $<5 \mathrm{hPa}$ stands for wet air conditions and VPD $>5 \mathrm{hPa}$ for dry air conditions. 95\% confidence intervals (lower and upper) for $L E$ (black dotted line) and $\mathrm{LE}_{\mathrm{b}}$ (grey dotted line) are also indicated.

In 'winter', the evaporation from the bottom layer contributes to the overall evaporation by $25 \%$ in dry conditions and $35 \%$ in wet conditions (Table 2). In 'summer', as the understorey vegetation grows, evaporation from the forest floor contributes up to $45 \%$ of the overall evaporation in dry air and water-stressed conditions.

The annual contribution of the understorey is $38 \%$ of the overall evaporation and $32 \%$ of the overall sensible heat flux (Table 2). Annual evaporation (Fig. 6a) from the understorey is $384 \mathrm{MJ} \mathrm{m}^{-2}(154 \mathrm{~mm})$ and $614 \mathrm{MJ} \mathrm{m}^{-2}(245 \mathrm{~mm})$ from the overstorey. Since the understorey vegetation is photosynthetically active from early spring to late autumn, canopy transpiration 
contributes substantially to the total ecosystem evaporation during this period. This contribution appears larger than that observed in other studies performed in pine forests. Berbigier et al. (1996) found that the understorey accounted for only 19\% of the total evapotranspiration in a pine forest in Portugal. Even if their stand was similar to the present one in terms of tree density and LAI, the major difference came from the composition of the understorey, which was essentially a bare soil with sparse shrubs. The climate type was also Mediterranean while it is Oceanic in our study. An earlier study performed on the same site as the present study, at a much earlier stage of forest growth (Diawara et al., 1991), shows that understorey contribution was around 25\%. A first explanation is that the conditions were not as dry as in our study. Another reason is also that tree density was twice as large as in the present study, and the LAI larger. This reinforces the fact that the understorey takes an important part in the water exchange of more open ecosystems. Indeed, in most open forests, the understorey participation to total evaporation ranges from 20 to $40 \%$ in Jack pine stands (Baldocchi and Vogel, 1996; Moore et al., 2000) and a boreal Scots pine forest (Launiainen et al., 2005), from 30 to $50 \%$ in temperate pine forests (Baldocchi et al., 2000) to 50\% and more in some high-latitude forests (Kelliher et al., 1997), the higher values occurring when the conditions become warmer and dryer. In denser and closer canopies, Black and Kelliher (1989) and Wilson et al. (2000) found that forest floor evaporation is between 3 and 21\% of total evapotranspiration.

In wet air conditions the Bowen ratio $(\beta=\mathrm{H} / \mathrm{LE})$ around midday is less than one above and below the canopy. In dry air conditions $\beta>1$ above the canopy and $\beta \approx 1$ below, except in well-watered conditions $(\beta<1)$. When water does not limit evaporation, most of the net radiation is dissipated as latent heat fluxes, but as the soil dries out, less water becomes available for understorey transpiration and more energy is dissipated as sensible heat. This is in agreement with Baldocchi et al. (2000), who found a large increase in $\beta$ as the surface was drying in a ponderosa pine forest. It is also noticeable that in 'winter', the ecosystem behaves as in a water-stressed 'summer', which confirms that the ecosystem is stressed in winter 2002, even if the level of water availability is not as low as during a stressed 'summer'. Indeed, the water table remained below the root zone depth resulting in a winter moisture deficit that may have produced an unusual needle senescence leading to a substantial litterfall, as was observed in February. Such unusual needle mortality was also observed at three other evenaged maritime pine stands in the same region as this study, differing in age, and corresponded to reductions in LAI (Delzon and Loustau, 2005). Roig et al. (2005) have also reported 
another peak for litter fall in winter in maritime pines in Spain, which was related to a moisture deficit.
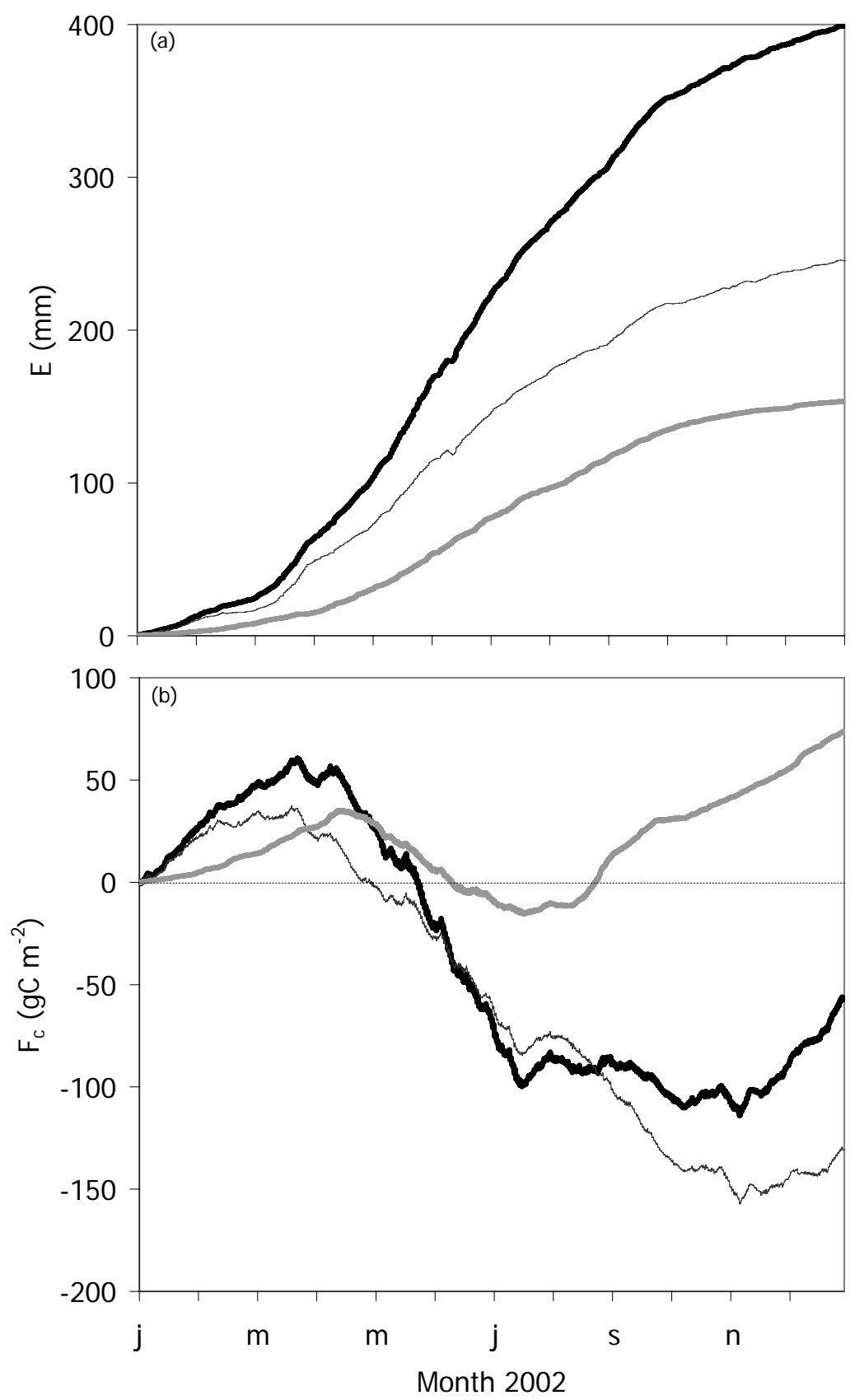

Figure 6. Cumulative (a) transpiration (E) above the forest (black), above the understorey (grey) and of the overstorey (thin black); (b) $\mathrm{CO}_{2}$ flux $\left(\mathrm{F}_{\mathrm{c}}\right.$ ) above the forest (black), above the understorey (grey) and of the overstorey (thin black).

\subsection{Seasonal variation in carbon dioxide fluxes}

The diurnal variations in Fc averaged over the 6 classes (Fig. 7) show positive values at night and negative values during the day, except in 'winter' at the understorey level where the daytime flux is slightly directed upwards in wet air conditions (Fig. 7.1). This means that 
during 'winter', $\mathrm{CO}_{2}$ is lost from the forest floor at a rate of $0.5 \mu \mathrm{mol} \mathrm{m}{ }^{-2} \mathrm{~s}^{-1}$ as a result of root and microbial respiration. Nevertheless, there is evidence for photosynthesis by the understorey vegetation: a net daytime uptake from the forest floor is observed at high VPD (Fig. 7.2) and even at low VPD, the small difference between night and day indicates a slight $\mathrm{CO}_{2}$ uptake (Fig. 7.1). In fact, class 1 is mostly composed of days in the periods from early January to mid-March, and from early November to late December, whereas class 2 (Fig. 7.2) is mostly composed of days from mid-March to the end of April. As in winter the soil is mainly covered by dead pine needles and patches of oat grasses (Pseudarrhenatherum longifolium), the small carbon uptake observed in Fig.7.1 comes from the slight photosynthesis activity of oat grass patches. At higher VPD (Fig. 7.2) corresponding to warmer days of March and April, the higher uptake is obviously due to the presence of purple moor-grass in addition to oat grass. This potential of photosynthesis to offset soil respiration shows the ability of oat grass and purple moor-grass to uptake $\mathrm{CO}_{2}$ at low radiation levels, as already observed with different understorey species in a boreal forest ecosystem (Whitehead and Gower, 2001).

In 'summer', both forest ecosystem and understorey vegetation photosynthesis are larger than respiration during the day. Under well-watered conditions (Fig. 7.3 and 7.4) and at about midday, the mean rate of $\mathrm{CO}_{2}$ fluxes reaches $-6 \mu \mathrm{mol} \mathrm{m} \mathrm{m}^{-2}$ and $-2 \mu \mathrm{mol} \mathrm{m} \mathrm{s}^{-1}$ for the overstorey and understorey, respectively. In these conditions, the understorey participates to $20 \%$ of daytime overall assimilation. Contrary to what is observed for latent heat fluxes (Fig. 4.3 and 4.4), air dryness does not influence $\mathrm{CO}_{2}$ assimilation in well-watered conditions. Together, this means that the stomatal conductance of the understorey is relatively constant, so that the latent heat flux increases with VPD while the $\mathrm{CO}_{2}$ flux does not change. When the soil water deficit becomes larger, the tree carbon uptake is higher at low VPD (Fig. 7.5) and lower at high VPD (Fig. 7.6) while the understorey carbon uptake is lower at low VPD and slightly larger at high VPD. Therefore, in water-stressed conditions the understorey participation raises from $4 \%$ to $30 \%$ as the air dries and the overstorey stomata close up. Again, this is well connected with the transpiration of understorey vegetation, which is low in wet air conditions (Fig 4.5) and higher in dry air conditions (Fig. 4.6). The percentage of standard deviation from the maximum values of $\mathrm{CO}_{2}$ fluxes varies from 51 to $100 \%$ above the canopy and 79 and 560\% under the canopy. The highest uncertainty occurs in winter with low VPD, when the fluxes are close to 0.

During the night, the ecosystem respiration is larger above $\left(2.1-4 \mu \mathrm{mol} \mathrm{m} \mathrm{m}^{-2} \mathrm{~s}^{-1}\right)$ than below (0.6-1.1 $\mu \mathrm{mol} \mathrm{m} \mathrm{m}^{-2} \mathrm{~s}^{-1}$ ) the canopy, leading to needle and bole respiration rates from 1.1 to 
$3.2 \mu \mathrm{mol} \mathrm{m} \mathrm{m}^{-2}$. These results should be considered carefully because the estimates below the canopy are usually representative of a much smaller area than the measurements above the canopy (Baldocchi, 1997; Wilson and Meyers, 2001). This often leads to an underestimation of understorey $\mathrm{CO}_{2}$ efflux when compared to chamber measurements (Norman et al., 1997; Kabwe et al., 2005), although some authors (Law et al., 1999) found a good agreement between both methods. However, averaging half-hourly values over several days should decrease the errors caused by the presence of heterogeneities under forest canopies (Baldocchi and Meyers, 1991).

The annual ecosystem carbon budget is negative $\left(-57 \mathrm{gC} \mathrm{m}^{-2}\right.$; Fig. 6b). During the year, the bottom layer is generally a source of carbon, with an annual budget is $+74 \mathrm{gC} \mathrm{m}^{-2}$, except from mid-June to late August when grass photosynthesis is larger than soil respiration. On a yearly basis, the overstorey behaves as a sink of $-131 \mathrm{gC} \mathrm{m}^{-2}$. It is noteworthy that it acts as a source of carbon between January and May, which is unusual at this site. Generally, photosynthesis is higher than respiration rate, resulting either in negative or slightly positive cumulative carbon flux pattern at the beginning of the year. It has to be pointed out that this unusual pattern observed in 2002 results in a very low annual ecosystem carbon uptake compared to other years at this site. Indeed, the annual $\mathrm{CO}_{2}$ sequestration was between -400 and $-500 \mathrm{gC} \mathrm{m}^{-2}$ during the 1997 and 1998 studies (Berbigier et al., 2001). Soil water availability in winter is twice as low as usually observed at this site, thus possibly reducing pine photosynthesis and increasing respiration in 2002. The substantial litterfall observed in February may have altered the photosynthesis capacity of the forest crown in winter and subsequent months, during the growing season. Medlyn et al. (2002) showed that the biochemical potential of photosynthesis of maritime pine needles is still high in winter, although it depends on temperature. 

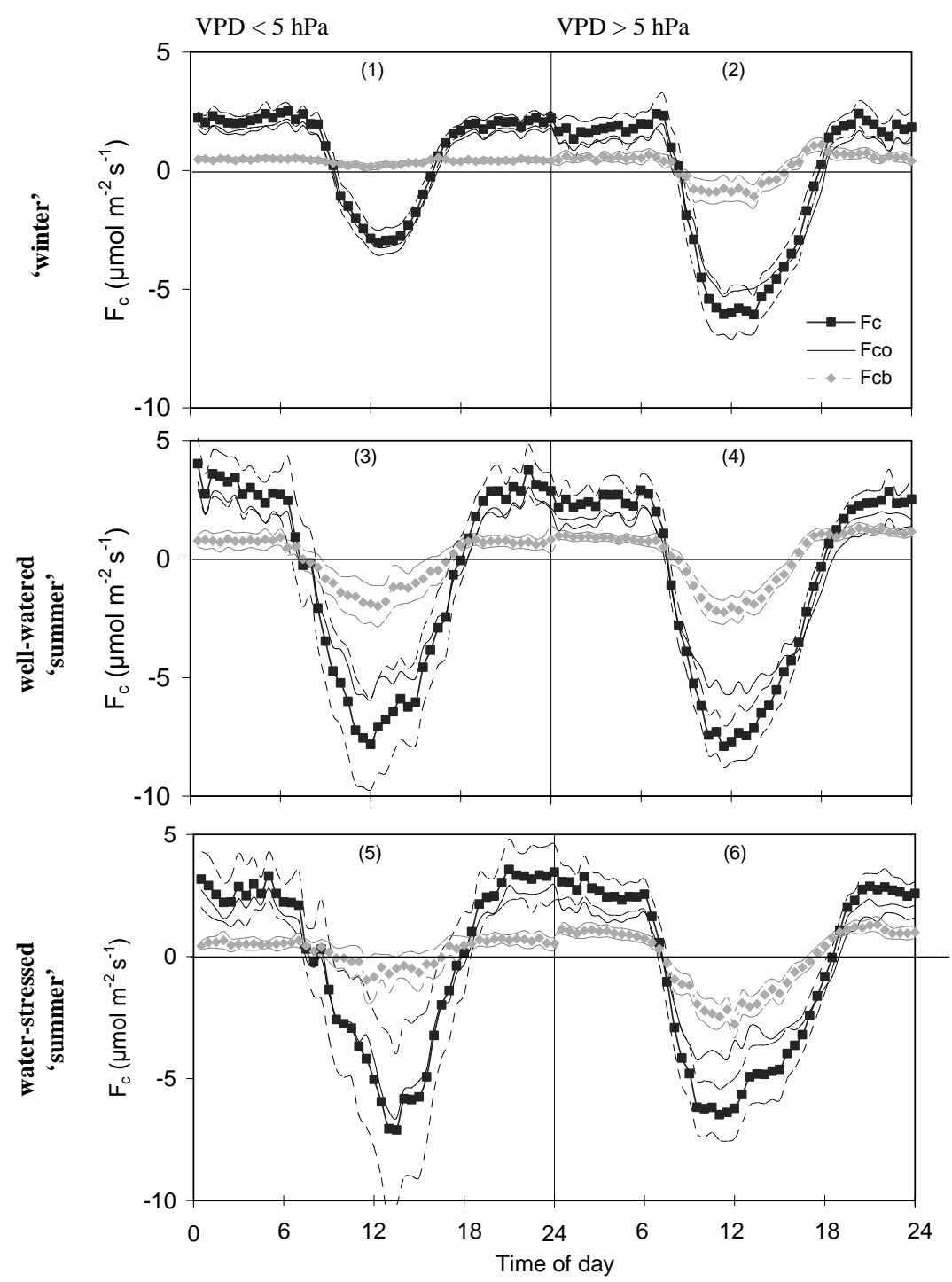

Figure 7. Mean daily course of $\mathrm{CO}_{2}$ fluxes above, $\mathrm{F}_{c}$, and below, $\mathrm{F}_{\mathrm{cb}}$, the canopy averaged over the six classes defined in Table $1 . \mathrm{F}_{\mathrm{co}}$ is the $\mathrm{CO}_{2}$ flux of the overstorey, deduced from the difference between the two levels. The classes are numbered from top left (1) to bottom right (6). 'Winter' refers to the period between early May to late October and 'summer' to the rest of the year. VPD $<5$ hPa stands for wet air conditions and VPD $>$ hPa for dry air conditions. 95\% confidence intervals (lower and upper) for $F_{c}$ (black dotted line) and $F_{c b}$ (grey dotted line) are also indicated.

\subsection{Seasonal variation in GPP and respiration}

Total daily GPP varies from 1 to $4 \mathrm{gC} \mathrm{m}^{-2}$ during winter and reaches $10 \mathrm{gC} \mathrm{m}^{-2}$ during summer, with significant depletion in stressed conditions (Fig. 8). Understorey GPP exhibits large variations between winter and summer, following the growth of the main understorey species, i.e. the purple moor grass that reaches its maximum LAI in July. However, it did not appear to decrease in the presence of a soil water deficit and varied between 2 and $5 \mathrm{gC} \mathrm{m}^{-2}$ from early May to late August. It can be seen from Fc fluxes that understorey GPP is not zero during winter, which confirms the existence of a slight photosynthesis activity of the other species composing the understorey at this period. We conclude that understorey GPP plays a 
significant role in the annual variations of total ecosystem GPP. Tree GPP, estimated as the difference between the total and understorey GPP, varies between $2 \mathrm{gC} \mathrm{m}^{-2}$ in winter and $6 \mathrm{gC} \mathrm{m}^{-2}$ in summer. As noticed for latent heat fluxes, the annual sum of GPP is also low in 2002, about 40\% less than for the 1997-1998 period analysed by Berbigier et al (2001) and Medlyn et al (2005). The lag of the understorey GPP behind the pines compared to the overstorey GPP is explained by the respective phenology of the species. Understorey LAI peaks on day 210 which explains the pattern of understorey GPP and R. Also, the understorey species is largely not sensitive to soil drought. Conversely, the pine's GPP decreases at the onset of soil drought on day 170 .

The daily respiration of the ecosystem ranges from 2 to $8 \mathrm{gC} \mathrm{m}^{-2}$ while that of the understorey ranges from 0 in winter to $4 \mathrm{gC} \mathrm{m}^{-2}$ in summer (Fig. 8). Partitioning respiration among the two canopy layers reveals the large proportion of respiration originating from the overstorey and the relatively low contribution of the understorey (Table 3). On an annual basis the overstorey layer indeed contributes to almost two thirds of the ecosystem respiration. Considering that trees also contribute to the bottom layer respiration through their root system, we conclude that autotrophic respiration largely dominates the respiration flux in 2002. On an annual basis respiration is reduced to a smaller extent than GPP, resulting in a dramatic decline in the annual net ecosystem exchange, that reaches its lowest annual value over the whole period 1997-2006 (unpublished results) and makes the site close to neutral in 2002. It has to be noticed that the discrepancies between measured Fc and values estimated from GPP-R for each canopy layer (Table 3) are rather small and can be attributed to the uncertainty on model parameters.

Table 3. Partitioning of the annual sum of carbon flux components for each ecosystem compartment expressed in $\mathrm{gC}^{-2} \mathrm{y}^{-1} . \mathrm{F}_{\mathrm{c}}$ are values measured by eddy covariance.

\begin{tabular}{lllll}
\hline & $\mathrm{F}_{\mathrm{C}}$ & $\mathrm{GPP}$ & $\mathrm{R}$ & $\mathrm{GPP}-\mathrm{R}$ \\
\hline Total & -57 & 1167 & 1088 & 79 \\
Understorey & 74 & 295 & 354 & -59 \\
& & & & \\
\hline Tree layer & -131 & 872 & 734 & -138
\end{tabular}

Coinciding with radiation variations, total GPP is almost three times as large in 'summer' as in 'winter' under wet conditions but under dry conditions it shows comparatively little variation (Fig. 9). GPP partitioning between the overstorey and understorey compartments varies according to seasonal and weather classes. Overstorey GPP, i.e., the difference between the two measurement levels, is sensitive to climate and soil water. It peaks in 'summer' at low 
VPD (Fig. 9.3 and 9.5), and it is strongly diminished by soil water deficit at high VPD (Fig. 9.6). Understorey GPP is significant only during the growing season of the main species, the purple moor grass. It shows little sensitivity to the levels of vapour deficit under well-watered conditions in 'summer'. However, it increases with VPD levels in 'winter' and decreases with VPD levels in 'summer' under water-stressed conditions, in agreement with the behaviour of latent heat flux (Fig. 5). As opposed to the current understanding of the effect of soil water deficit on photosynthesis (Granier et al., 2007), the understorey GPP is even maximum for the class of low soil water and high VPD and it almost equals the pine GPP (Fig. 9.6). Indeed, the understorey layer appears to be well decoupled from the prevailing weather conditions so that gaseous exchanges from the bottom layer are mainly conditioned by its LAI dynamics and the radiation regime (Loustau et al., 1998). We conclude that the annual course of total GPP is actually the result of contrasted behaviour of its two components, with an enhanced contribution of the understorey in mid-summer and predominance of the pine photosynthesis in winter, spring and autumn (Fig. 8). Whether this pattern changes from year to year in relationship with the soil water regime will be further analyzed.

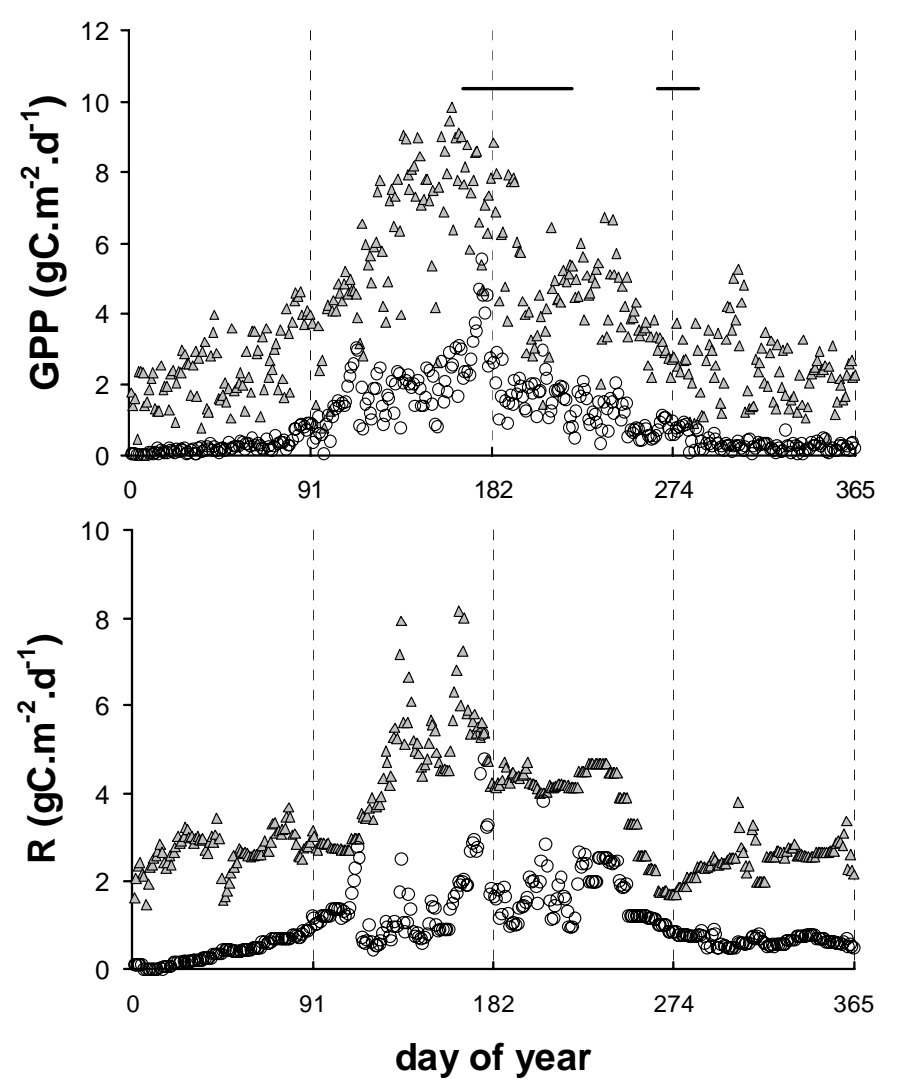

Figure 8. Annual course of daily gross primary productivity, GPP, and respiration, R, for the entire ecosystem (triangles) and the bottom layer (Molinia grass and soil, open circles), as estimated from the $\mathrm{CO}_{2}$ fluxes at the two levels. Horizontal bars in the top graph delineate the periods where the soil water content was below $65 \mathrm{~mm}$. 

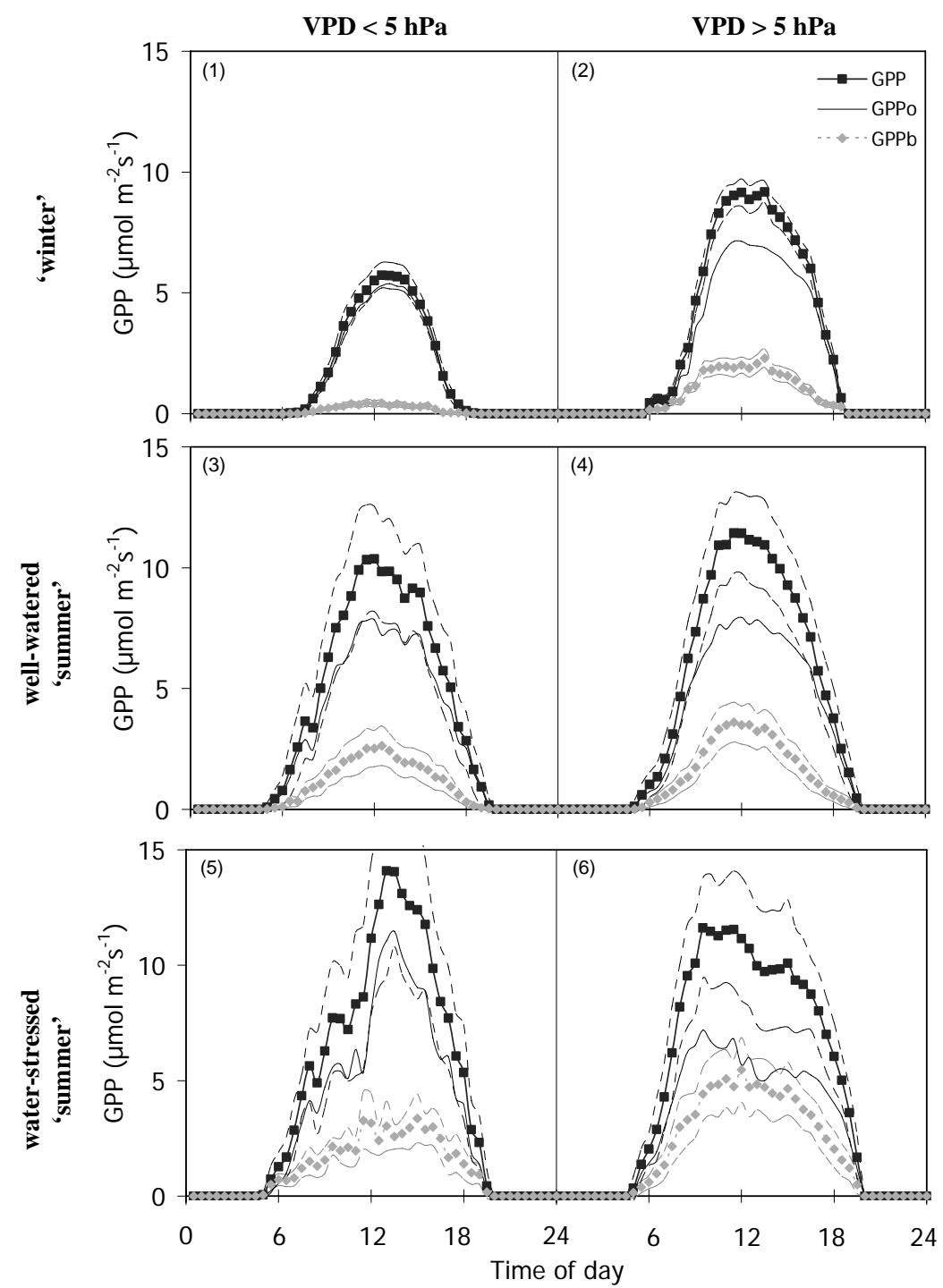

Figure 9. Mean daily course of gross primary productivity, GPP, above the canopy (black symbols), below the canopy (grey symbol) and of the difference between the two levels (broken line) averaged over the six classes defined in Table 1. The classes are numbered from top left (1) to bottom right (6). 'Winter' refers to the period between early May to late October and 'summer' to the rest of the year. VPD $<5$ hPa stands for wet air conditions and VPD > hPa for dry air conditions. 95\% confidence intervals (lower and upper) for GPP (black dotted line) and GPP (grey dotted line) are also indicated.

\subsection{Water use efficiency}

To further investigate the response of the maritime pine forest ecosystem to drought, we examined the water use efficiency for each weather class (Table 4). As expected, WUE increases in summer with increasing soil water deficit and decreases with increasing VPD. The pine tree canopy uses water more efficiently than the understorey, whose contribution to the overall ecosystem WUE is low. It has to be pointed out that the understorey evaporation includes both water use by the vegetation and soil evaporation, which may account for this difference between the two canopy layers. 
Also, the fact that understorey photosynthesis and transpiration shows a reduced sensitivity to climate and soil as well as inefficient stomatal control is consistent with its lower water use efficiency. On the other hand, it contrasts with the pine behaviour which exhibits a drought avoidance strategy with earlier stomatal limitation of water loss under dry conditions (Loustau et al., 1996; Picon et al., 1996).

Table 4. Ecosystem, understorey (index b) and overstorey (index o) water use efficiencies (WUE) expressed in mmol $\mathrm{C} \mathrm{mol} \mathrm{H}_{2} \mathrm{O}^{-1}$ for the weather classes defined in Table 1. The calculation was made over the whole data set.

\begin{tabular}{llll}
\hline & WUE & WUEb & WUEo \\
\hline $\mathbf{1}$ & 3.6 & 0.9 & 3.9 \\
$\mathbf{2}$ & 2.9 & 2.2 & 2.8 \\
$\mathbf{3}$ & 3.5 & 2.4 & 3.4 \\
$\mathbf{4}$ & 3.2 & 2.1 & 3.2 \\
$\mathbf{5}$ & 4.1 & 3.6 & 3.8 \\
$\mathbf{6}$ & 3.5 & 3.1 & 3.2 \\
& & & \\
year & 3.3 & 2.3 & 3.2 \\
\hline
\end{tabular}

\section{SUMMARY AND CONCLUSIONS}

$\mathrm{CO}_{2}$, water and energy exchanges were investigated above and within a maritime pine forest during the year 2002, which displayed a period of unusual reduced soil water availability, lasting from winter 2001/2002 to the beginning of October 2002. The energy balance closure was found adequately good at both levels, to the exception of an underestimation of turbulent fluxes at low radiation levels above the canopy and an underestimation of net radiation at the soil surface. At the bottom level, the underestimation of net radiation was attributed to the difficulty in accurately estimating the leaf area index in a coniferous forest, which is a challenge for future years.

We showed that the annual course of overall fluxes resulted from contrasted dynamics of the overstorey and understorey layers, according to meteorological conditions. In response to the reduced soil water availability, the ecosystem dissipated much less energy via latent heat flux and more as sensible heat flux as compared with what is usually observed at this site. Moreover, because of the openness of the maritime pine forest, the understorey canopy was responsible for a significant and variable component of the total water vapour and carbon dioxide fluxes. The contribution of the understorey might be as large as $45 \%$ of the overall evaporation and $30 \%$ of the daytime overall assimilation during summer with a significant 
soil water deficit. Even in winter, $\mathrm{CO}_{2}$ fluxes from the forest floor were not negligible. However, due to the noteworthy deficit in soil water during winter, the maritime pine ecosystem behaved as a source of carbon during the first months of the year. This led to a low annual value of ecosystem GPP, 40\% less than usually observed at this site, and a high overstorey respiration, almost two thirds of the ecosystem respiration.

During summer drought, the grass species composing the understorey and the maritime pine trees adopted different strategies in response to soil water deficit. Pine trees followed a drought-avoiding strategy while the grasses did not exhibit a clear marked control on the understorey evaporation.

We observe that the short term heat and drought period that occurred during the summer of the following year, 2003 (Ciais et al. 2005), depleted the carbon balance of the site much less than what was induced in 2002 by the long lasting soil water deficit. Indeed in 2003, even though the pines may have released $\mathrm{CO}_{2}$ during the summer heat and drought, the forest recovered quickly and the annual pattern in 2003 was not as affected as it was in 2002.

This study is being extended to other years in order to draw additional conclusions on the long-term behaviour of this two-layer canopy, and detect the effects of climatic anomalies like heat and drought events experienced in 2003 and 2005. Higher frequency of similar events is expected in the future.

\section{Acknowledgements}

This work was partly supported by the CarboEurope-IP project. 


\section{Reference list}

Aubinet, M., A. Grelle, A. Ibrom, U. Rannik, J. Moncrieff, T. Foken, A.S. Kowalski, P.H. Martin, P. Berbigier, C. Bernhofer, R. Clement, J. Elbers, A. Granier, T. Grünwald, K. Morgenstern, K. Pilegaard, C. Rebmann, W. Snijders, R. Valentini and T. Vesala, 2000. Estimates of the annual net carbon and water exchange of forests: the EUROFLUX methodology. Advances in Ecological Research. 30, 113-175.

Baldocchi, D., 1997. Flux footprints within and over forest canopies. Boundary-Layer Meteorology. 85, 273-292.

Baldocchi, D. and Meyers, T., 1991. Trace gas exchange above the floor of a decideous forest. 1. Evaporation and $\mathrm{CO}_{2}$ efflux. Journal of Geophysical Research. 96(D4), 72717285.

Baldocchi, D.D., E. Falge, L. Gu, R. Olson, D. Hollinger, S. Running, P. Anthoni, C. Bernhofer, K. Davis, J. Fuentes, A. Goldstein, G. Katul, B. Law, X. Lee, Y. Malhi, T. Meyers, J.W. Munger, W. Oechel, K. Pilegaard, H.P. Schmid, R. Valentini, S. Verma, T. Vesala, K. Wilson and S. Wofsy, 2001. FLUXNET: A new tool to study the temporal and spatial variability of ecosystem-scale carbon dioxide, water vapor and energy flux densities. Bulletin of the American Meteorological Society. 82(11), 2415-2434.

Baldocchi, D.D., Law, B.E. and Anthoni, P.M., 2000. On measuring and modeling energy fluxes above the floor of a homogeneous and heterogeneous conifer forest. Agricultural and Forest Meteorology. 102(2-3), 187-206.

Baldocchi, D.D. and Vogel, C.A., 1996. Energy and $\mathrm{CO}_{2}$ flux densities above and below a temperate broad-leaved forest and a boreal pine forest. Tree Physiology. 16, 5-16.

Berbigier, P. and Bonnefond, J.M., 1995. Measurements and modeling of radiation transmission within a stand of maritime pine, Pinus pinaster Ait.). Ann. Sci. For. 52, 23-42.

Berbigier, P., J.M. Bonnefond, D. Loustau, M.I. Ferreira, J.S. David and J.S. Pereira, 1996. Transpiration of a 64-year old maritime pine stand in Portugal. 2. Evapotranspiration and canopy stomatal conductance measured by an eddy covariance technique. Oecologia. 107, 43-52.

Berbigier, P., Bonnefond, J.M. and Mellmann, P., 2001. $\mathrm{CO}_{2}$ and water vapour fluxes for 2 years above Euroflux forest site. Agricultural and Forest Meteorology. 108, 183-197.

Black, T.A. and Kelliher, F.M., 1989. Processes controlling understorey evapotranspiration. Philosophical Transactions of the Royal Society of London. Series B: Biological Sciences. 324, 207-231.

Blanken, P.D., T.A. Black, P.C. Yang, H.H. Neumann, Z. Nesic, R. Staebler, G. den Hartog, M.D. Novak and X. Lee, 1997. Energy balance and canopy conductance of a boreal aspen forest: partitioning overstory and understory components. Journal of Geophysical Research. 102, 28,915-28,927.

Blanken, P.D., T.A. Black, H.H. Neumann, G. Den Hartog, P.C. Yang, Z. Nesic, R. Staebler, R. Chen and M.D. Novak, 1998. Turbulent flux measurements above and below the overstory of a boreal aspen forest. Boundary-layer Meteorology. 89(1), 109-140.

Ciais, P., M. Reichstein, N. Viovy, A. Granier, J. Ogée, V. Allard, M. Aubinet, N. Buchmann, C. Bernhofer, A. Carrara, F. Chevallier, N. De Noblet, A. Friend, P. Friedlingstein, T. Grünwald, B. Heinesch, P. Keronen, A. Knohl, G. Krinner, D. Loustau, G. Manca, G. Matteucci, F. Miglietta, J.M. Ourcival, D. Papale, K. Pilegaard, S. Rambal, G. Seufert, J.F. 
Soussana, M.J. Sanz, E.D. Schulze, T. Vesala and R. Valentini, 2005. Europe-wide reduction in primary productivity caused by the heat and drought in 2003. Nature. 437, 529-533.

Delzon, S. and D. Loustau, 2005. Age-related decline in stand water use: sap flow and transpiration in a pine forest chronosequence. Agricultural and Forest Meteorology. 129, 105-119.

Diawara, A., Loustau, D. and Berbigier, P., 1991. Comparison of two methods for estimating the evaporation of a Pinus pinaster (Ait.) stand: sap flow and energy balance with sensible heat flux measurements by an eddy covariance method. Agricultural and Forest Meteorology. 54, 49-66.

Falge, E., D. Baldocchi, R. Olson, P. Anthoni, M. Aubinet, C. Bernhofer, G. Burba, R. Ceulemans, R. Clement, H. Dolman, A. Granier, P. Gross, T. Grunwald, D. Hollinger, N.O. Jensen, G. Katul, P. Keronen, A. Kowalski, C.T. Lai, B.E. Law, T. Meyers, J. Moncrieff, E. Moors, J. Munger, K. Pilegaard, U. Rannik, C. Rebmann, A. Suyker, J. Tenhunen, K. Tu, S. Verma, T. Vesala, K. Wilson and S. Wofsy, 2001a. Gap filling strategies for defensible annual sums of net ecosystem exchange. Agricultural and Forest Meteorology. 107, 43-69.

Falge, E., D. Baldocchi, R. Olson, P. Anthoni, M. Aubinet, C. Bernhofer, G. Burba, R. Ceulemans, R. Clement, H. Dolman, A. Granier, P. Gross, T. Grunwald, D. Hollinger, N.O. Jensen, G. Katul, P. Keronen, A. Kowalski, C.T. Lai, B.E. Law, T. Meyers, J. Moncrieff, E. Moors, J. Munger, K. Pilegaard, U. Rannik, C. Rebmann, A. Suyker, J. Tenhunen, K. Tu, S. Verma, T. Vesala, K. Wilson and S. Wofsy, 2001b. Gap-filling strategies for long term energy flux data sets. Agricultural and Forest Meteorology. 107, 71-77.

Giorgi, F. (2006). Climate change hot-spots. Geophysical Research Letters, 33:L08707.

Granier, A. and Loustau, D., 1994. Measuring and modelling the transpiration of a maritime pine canopy from sap-flow data. Agricultural and Forest Meteorology, 71: 61-81.

Granier, A., M. Reichstein, N. Breda, I. A. Janssens, E. Falge, P. Ciais, T. Grunwald, M. Aubinet, P. Berbigier, C. Bernhofer, N. Buchmann, O. Facini, G. Grassi, B. Heinesch, H. Ilvesniemi, P. Keronen, A. Knohl, B. Kostner, F. Lagergren, A. Lindroth, B. Longdoz, D. Loustau, J. Mateus, L. Montagnani, C. Nys, E. Moors, D. Papale, M. Peiffer, K. Pilegaard, G. Pita, J. Pumpanen, S. Rambal, C. Rebmann, A. Rodrigues, G. Seufert, J. Tenhunen, T. Vesala and Q. Wang, 2007. Evidence for soil water control on carbon and water dynamics in European forests during the extremely dry year: 2003. Agricultural and Forest Meteorology. 143(1-2), 123-145.

Guyon, D., Berbigier, P., Courrier, G., Lagouarde, J.P. and Moreau, P., 2003. Estimation du LAI dans un écosystème cultivé de pin maritime à partir des mesures de fractions de trouées directionnelles. Canadian Journal of Remote Sensing. 29, 336-348.

Kabwe, L.K., Farrell, R.E., Carey, S.K., Hendry, M.J. and Wilson, G.W., 2005. Characterizing spatial and temporal variations in $\mathrm{CO}_{2}$ fluxes from ground surface using three complimentary measurement techniques. Journal of Hydrology. 311(1-4), 80-90.

Kelliher, F.M., D.Y. Hollinger, E.D. Schulze, N.N. Vygodskaya, J.N. Byers, J.E. Hunt, T.M. McSeveny, I. Milukova, A. Sogatchev, A. Varlargin, W. Ziegler, A. Arneth and G. Bauer, 1997. Evaporation from an eastern Siberian larch forest. Agricultural and Forest Meteorology. 85, 135-147. 
Kohsiek, W., C. Liebethal, T. Foken, R. Vogt, S. P. Oncley, C. Bernhofer and H. A. R. Debruin, 2007. The Energy Balance Experiment EBEX-2000. Part III: Behaviour and quality of the radiation measurements. Boundary Layer Meteorology. 123, 55-75.

Lamaud, E., Ogée, J., Brunet, Y. and Berbigier, P., 2001. Validation of eddy flux measurements above the understorey of a pine forest. Agricultural and Forest Meteorology. 106, 187-203.

Launiainen, S., J. Rinne, J. Pumpanen, L. Kulmala, P. Kolari, P. Keronen, E. Siivola, T. Pohja, P. Hari and T. Vesala, 2005. Eddy covariance measurements of $\mathrm{CO}_{2}$ and sensible and latent heat fluxes during a full year in a boreal pine forest trunk-space. Boreal Environment Research. 10, 569-588.

Law, B.E., Baldocchi, D.D. and Anthoni, P.M., 1999. Below-canopy and soil $\mathrm{CO}_{2}$ fluxes in a ponderosa pine forest. Agricultural and Forest Meteorology. 94(3-4), 171-188.

Loustau, D. and Cochard, H., 1991. Utilisation d'une chambre de transpiration portable pour l'estimation de l'évapotranspiration d'un sous-bois de pin maritime à molinie (Molinia coerulea (L) Moench). Annals of Forest Science. 48, 29-45.

Loustau, D., Berbigier, P., Roumagnac, P., Arruda-Pacheco, C., David, J.S., Ferreira, M.I., Pereira, J.S. and Tavares, R., 1996. Transpiration of a 64-year old maritime pine stand in Portugal. 1. Seasonal course of water flux through maritime pine. Oecologia, 107: 33-42.

Loustau, D., P. Berbigier and K. Kramer, 1998. Sensitivity of the water balance of southwestern France maritime pine forests to climate. International Conference on impacts of global change on tree physiology and forest ecosystems. Wageningen, 26-29 November 1996. G. M. J. "Mohren, K. Kramer and S. Sabate. Dordrecht (Netherlands), Kluwer Academic Publishers: 193-205.

Medlyn, B.E., Loustau, D. and Delzon, S., 2002. Temperature response of parameters of a biochemically based model of photosynthesis. I. Seasonal changes in mature maritime pine (Pinus pinaster Ait.). Plant, Cell and Environment. 25, 1155-1165.

Medlyn, B.E., P. Berbigier, R. Clement, A. Grelle, D. Loustau, S. Linder, L. Wingate, P.G. Jarvis, B.D. Sigurdsson and R.E. McMurtrie, 2005. Carbon balance of coniferous forests growing in contrasting climates: Model-based analysis. Agricultural and Forest Meteorology. 131(1-2), 97-124.

Meehl, G.A. and C. Tebaldi (2004). More Intense, More Frequent, and Longer Lasting Heat Waves in the 21st Century. Science, 305:994-997.

Misson, L., D.D. Baldocchi, T.A. Black, P.D. Blanken, Y. Brunet, J. Curiel Yuste, J.R. Dorsey, M. Falk, A. Granier, M.R. Irvine, N. Jarosz, E. Lamaud, S. Launiainen, B.E. Law, B. Longdoz, D. Loustau, M. McKay, K.T. Paw U, T. Vesala, D. Vickers, K.B. Wilson and A.H. Goldstein, 2007. Partitioning forest carbon fluxes with overstory and understory eddy-covariance measurements: A synthesis based on FLUXNET data. Agricultural and Forest Meteorology. 144, 14-31.

Moore, K.E., Fitzjarrald, D.R., Sakai, R.K. and Freedman, J.M., 2000. Growing season water balance at a boreal jack pine forest. Water Resources Research, 36: 483-493.

Norman, J.M., C.J. Kucharik, S.T. Gower, D.D. Baldocchi, P.M. Crill, M. Rayment, K. Savage and R.G. Striegl, 1997. A comparison of six methods for measuring soil-surface carbon dioxide fluxes. Journal of Geophysical Research-Atmospheres. 102(D24), 2877128777. 
Ogée, J., Brunet, Y., Loustau, D., Berbigier, P. and Delzon, S., 2003. MuSICA, a $\mathrm{CO}_{2}$, water and energy multilayer, multileaf pine forest model: evaluation from hourly to yearly time scales and sensitivity analysis. Global Change Biology. 9(5), 697-717.

Ogée, J., Lamaud, E., Brunet, Y., Berbigier, P. and Bonnefond, J.M., 2001. A long-term study of soil heat flux under a forest canopy. Agricultural and Forest Meteorology. 106, 173-186.

Picon, C., Guehl, J.-M. and Ferhi, A., 1996. Leaf gas exchange and carbon isotope composition responses to drought in a drought-avoiding (Pinus pinaster) and a droughttolerant (Quercus petraea) species under present and elevated atmospheric $\mathrm{CO}_{2}$ concentrations. Plant, Cell and Environment. 19, 182-190.

Reichstein, M., E. Falge, D. Baldocchi, D. Papale, M. Aubinet, P. Berbigier, C. Bernhofer, N. Buchmann, T. Gilmanov, A. Granier, T. Grünwald, K. Havránková, H. Ilvesniemi, D. Janous, A. Knohl, T. Laurila, A. Lohila, D. Loustau, G. Matteucci, T. Meyers, F. Miglietta, J.M. Ourcival, J. Pumpanen, S. Rambal, E. Rotenberg, M. Sanz, J. Tenhunen, G. Seufert, F. Vaccari, T. Vesala, D. Yakir and R. Valentini, 2005. On the separation of net ecosystem exchange into assimilation and ecosystem respiration: review and improved algorithm. Global Change Biology. 11(9), 1424-1439.

Roig, S., M. del Rio, I. Canellas, G. Montero, 2005. Litter fall in Mediterranean Pinus pinaster Ait. stands under different thinning regimes. Forest Ecology and Management 206(1-3): 179-190.

Valentini, R., 2003. Fluxes of carbon, water and energy of European forests. Ecological Studies, 163. Springer.

Webb, E.K., Pearman, G.I. and Leuning, R., 1980. Correction of flux measurements for density effects due to heat and water transfer. Quaterly Journal of the Royal Meteorological Society. 106, 85-100.

Whitehead, D. and Gower, S.T., 2001. Photosynthesis and light-use efficiency by plants in a Canadian boreal forest ecosystem. Tree Physiology. 21, 925-929.

Wilson, K. and Meyers, T., 2001. The spatial variability of energy and carbon dioxide fluxes at the floor of a deciduous forest. Boundary-Layer Meteorology. 98, 443-473.

Wilson, K.B., Hanson, P.J. and Baldocchi, D.D., 2000. Factors controlling evaporation and energy partitioning beneath a deciduous forest over an annual cycle. Agricultural and Forest Meteorology. 102, 83-103. 